\title{
Vitamin D status and pathway genes in five European autoimmune Addison's disease cohorts
}

\author{
Marissa Penna-Martinez ${ }^{1}$, Gesine Meyer ${ }^{1}$, Anette Boe Wolff ${ }^{2,7}$, Beate Skinningsrud ${ }^{3}$, Corrado Betterle ${ }^{4}$, \\ Alberto Falorni ${ }^{5}$, William Ollier ${ }^{6}$, Dag Undlien ${ }^{3}$, Eystein Husebye ${ }^{2,7}$, Simon Pearce ${ }^{8}$, Anna L Mitchell ${ }^{8}$ and \\ Klaus Badenhoop ${ }^{1}$
}

'Division of Endocrinology, Diabetes and Metabolism, Department of Internal Medicine I, University Hospital Frankfurt, Goethe-University, Germany, ${ }^{2}$ Department of Clinical Science and KG Jebsen Center for Autoimmune Disorders, University of Bergen, Bergen, Norway, ${ }^{3}$ Department of Medical Genetics, Oslo University Hospital and University of Oslo, Oslo, Norway, ${ }^{4}$ Department of Medicine (DIMED), University of Padua School of Medicine, Padua, Italy, ${ }^{5}$ Department of Internal Medicine, University of Perugia, Perugia, Italy, ${ }^{6}$ Faculty of Science and Engineering, Manchester Metropolitan University, Manchester, UK, 'Department of Medicine, Haukeland University Hospital, Bergen, Norway, and ${ }^{8}$ Translational \& Clinical Research Institute, Newcastle University, Newcastle, UK

Correspondence should be addressed to M Penna-Martinez Email

marissa.penna-martinez@ kgu.de

\begin{abstract}
Objective: While vitamin $D$ regulates immune cells, little is known about it in autoimmune Addison's disease (AAD). We investigated the vitamin D status in AAD patients from five European populations to assess its deficiency. In addition, we studied two case-control cohorts for vitamin D metabolism and pathway genes.

Design: Cross-sectional study.

Methods: A total of 1028 patients with AAD from Germany $(n=239)$, Italy $(n=328)$, Norway $(n=378)$, UK $(n=44)$ and Poland $(n=39)$ and 679 controls from Germany $(n=301)$ and Norway $(n=378)$ were studied for $25(\mathrm{OH}) \mathrm{D}_{3}$ (primary objective). Secondary objectives $\left(1,25(\mathrm{OH})_{2} \mathrm{D}_{3}\right.$ and pathway genes) were examined in case-controls from Germany and Norway correlating $25(\mathrm{OH}) \mathrm{D}_{3}$ and single nucleotide polymorphisms within genes encoding the vitamin $\mathrm{D}$ receptor (VDR), 1-a-hydroxylase (CYP27B1), 25-hydroxylase (CYP2R1), 24-hydroxylase (CYP24A1) and vitamin D binding protein (GC/DBP). Results: Vitamin D deficiency $\left(25(\mathrm{OH}) \mathrm{D}_{3} 10-20 \mathrm{ng} / \mathrm{mL}\right.$ ) was highly prevalent in AAD patients $(34-57 \%), 5-22 \%$ were severely deficient ( $<10 \mathrm{ng} / \mathrm{mL}), 28-38 \%$ insufficient ( $20-30 \mathrm{ng} / \mathrm{mL}$ ) and only $7-14 \%$ sufficient $(>30 \mathrm{ng} / \mathrm{mL}$ ). Lower $25(\mathrm{OH}) \mathrm{D}_{3}$ and $1,25(\mathrm{OH})_{2} \mathrm{D}_{3}$ levels were observed both in Norwegian and German AAD $\left(P=0.03 / 0.003\right.$ and $P=1 \times 10^{-}$ $5 /<1 \times 10^{-7}$, respectively) the former was associated with CYP2R1 (rs1553006) genotype G. Whereas controls achieved sufficient median $25(\mathrm{OH}) \mathrm{D}_{3}$ in summers (21.4 to $21.9 \mathrm{ng} / \mathrm{mL}$ ), AAD patients remained largely deficient (18.0 to $21.2 \mathrm{ng}$ / $\mathrm{mL}$ ) and synthesize less $1,25(\mathrm{OH})_{2} \mathrm{D}_{3}$.

Conclusion: Vitamin D deficiency and insufficiency are highly prevalent in AAD patients. The vitamin D status of AAD may be influenced by genetic factors and suggests individual vitamin $D$ requirements throughout the year.
\end{abstract}

\section{Introduction}

Autoimmune Addison's disease (AAD) is a rare disorder of the adrenal glands and may be a morbid component of autoimmune polyendocrine syndrome (APS) (1). Vitamin D deficiency is frequently observed in several autoimmune diseases (2). Furthermore, in rare cases of monogenic vitamin D system disorders autoimmune diseases such as type 1 diabetes or multiple sclerosis have been described $(3,4,5)$. This implies an enhanced 
risk for autoimmunity in association with vitamin D deficiency. In addition, genetic variation of the vitamin D activating enzyme CYP27B1 at the population level has been found to be associated with $\mathrm{AAD}$, in addition to other endocrinopathies such as type 1 diabetes, thyroid autoimmunity (6) and multiple sclerosis (7).

Vitamin D levels regulate both innate and acquired immunity through several mechanisms: vitamin D receptor (VDR) and the vitamin D biosynthetic enzymes are expressed in macrophages, monocytes, activated T-lymphocytes and B-lymphocytes (8). Experimental animal models lacking the VDR or the activating enzyme CYP27B1 show immune defects. In contrast, models with tissue specific VDR overexpression display anti-inflammatory effects as observed in airway cells $(9,10,11,12,13)$. Vitamin D facilitates extensive immune actions as shown by genome-wide analyses of vitamin D binding to chromatin. Vitamin D acts on distinct genes where the VDR interacts with other transcription factors to induce cellular signalling (14). This chromatin targeting has identified epigenomic regulators of disease susceptibility regions in type 1 diabetes and other autoimmune disorders (15).

Since the vitamin $\mathrm{D}$ status can be corrected by supplementation, it represents a remediable risk factor. We therefore investigated the vitamin D status, genetic variants of its activation, binding and metabolism in order to define requirements in $\mathrm{AAD}$ patients.

\section{Study participants and methods}

\section{Study design}

All study participants in this cross-sectional study (16) were recruited from February 2000 to June 2014 as part of the Euradrenal Consortium (www.euradrenal.org).

One thousand and twenty-eight AAD cases, Caucasian origin were included from Germany $(n=239)$,
Italy $(n=328)$, Norway $(n=378)$, UK $(n=44)$ and Poland $(n=39)$. The clinical diagnosis of all AAD patients was confirmed on the basis of a low basal serum cortisol with a high adrenocorticotropic hormone (ACTH) level (patient characteristics are provided in Table 1).

In addition, 679 individuals without autoimmune diseases and of Caucasian origin served as a control group: 301 Germans (166 female and 135 male; median age 33 years) and 378 Norwegian (132 female and 246 male; median age 45 years).

The primary study objective $25(\mathrm{OH}) \mathrm{D}_{3}$ was analysed in all participants. The secondary study objective $1,25(\mathrm{OH})_{2} \mathrm{D}_{3}$ was measured in German and Norwegian cases and healthy controls.

Finally a secondary analysis (in Norwegian cases and healthy controls) included 25 single nucleotide polymorphisms (SNPs) within genes that encode: VDR; 1- $\alpha$-hydroxylase; 25-hydroxylase (CYP2R1); 24-hydroxylase and vitamin $\mathrm{D}$ binding protein.

\section{Ethical approval}

The study participants were locally recruited from the corresponding Endocrine Outpatient Clinic of the different centres. Study protocols were approved by the regional Ethics Committees: Italy (Padua ref. No $1583 \mathrm{P}$ and Perugia ref. No 1247/08), Poland (Warsaw, ref. No 18/4/2007), Norway (Bergen ref. No 047.96 and 2013_1504), UK (Newcastle, ref. No 05/Q1206/144) and Germany (Frankfurt am Main, ref. No 49/09).

All analyses were carried out in accordance with the ethical votes from the contributing countries. The Ethics committees' votes included the analysis of Addison's disease risk factors in biological samples with pseudonymized patient data from the primary study (Euradrenal). All participants gave informed, written consent.

Table 1 Characteristics of the patients with autoimmune Addison's disease.

\begin{tabular}{ll} 
& \\
Country & Centre \\
\cline { 1 - 1 } Norway & Bergen \\
Germany & Frankfurt am Main \\
Italy & Perugia/Padua \\
Poland & Warsaw \\
United Kingdom & Newcastle
\end{tabular}

\begin{tabular}{|c|c|c|}
\hline \multicolumn{3}{|c|}{ AAD, $n$} \\
\hline Total & $\mathrm{F}$ & $\mathrm{M}$ \\
\hline 378 & 234 & 144 \\
\hline 239 & 179 & 60 \\
\hline 328 & 220 & 108 \\
\hline 39 & 29 & 10 \\
\hline 44 & 31 & 13 \\
\hline
\end{tabular}

\begin{tabular}{c} 
Age (years) at blood collection* \\
\hline $51(39-63)$ \\
$49(39-59)$ \\
$39(30-50)$ \\
$51(39-59)$ \\
$56(45-62)$
\end{tabular}

\begin{tabular}{c}
\hline APS2, $\boldsymbol{n}(\%)$ \\
\hline $193(51)$ \\
$136(57)$ \\
$180(55)$ \\
$26(67)$ \\
$16(36)$ \\
\hline
\end{tabular}

*Data presented as median (IQR).

AAD, autoimmune Addison's disease; APS2, polyglandular syndrome 2; F, female; M, male; IQR, interquartile range. 


\section{Determination of vitamin D metabolites}

Stored frozen plasma aliquots $\left(-80^{\circ} \mathrm{C}\right)$ obtained from the different participating centres were analysed in the hormone laboratory in the Department of Internal Medicine I, Frankfurt am Main. Both 25-hydroxyvitamin D3 $\left(25(\mathrm{OH}) \mathrm{D}_{3}\right)$ and 1,25-dihydroxyvitamin $\mathrm{D} 3\left(1,25(\mathrm{OH})_{2} \mathrm{D}_{3}\right)$ levels were measured using a RIA (for $25(\mathrm{OH}) \mathrm{D}_{3}$ DiaSorin, Stillwater, Minnesota, USA and for $1,25(\mathrm{OH})_{2} \mathrm{D}_{3}$ IDS, Frankfurt am Main, Germany). The assays were performed in accordance with the manufacturer's protocols. The intraassay variation coefficient $(\mathrm{CV})$ range from 8.6 to $12.5 \%$ in the $25(\mathrm{OH}) \mathrm{D}_{3}$, RIA and 8.4 to $12.9 \%$ in the $1,25(\mathrm{OH})_{2} \mathrm{D}_{3}$ RIA. Radioimmunoassays were standard at the time of analysis, had been applied for clinical use at the University of Frankfurt and used in numerous studies $(17,18)$. Routine quality control procedures were applied for both RIAs.

\section{Analysis of single nucleotide polymorphisms}

Five vitamin $\mathrm{D}$ pathway genes were analysed by the Euradrenal consortium: VDR (Chr12), CYP2R1 (25-hydroxylase, Chr11), CYP27B1 (Chr12), CYP24A1 (24-hydroxylase, Chr20), DBP (vitamin D binding protein, Chr4). The secondary analysis included the correlation of $25(\mathrm{OH}) \mathrm{D}_{3}$ and vitamin D-related gene polymorphisms within the mentioned genes. The majority of the investigated polymorphisms within these genes are located in the intron region:

rs11168275, rs10875693, rs2189480, rs2254210 rs3819545, rs10741661, rs11023374, rs1553006, rs4646536, rs703842, rs10876994, rs1570669, rs2181874, rs2209314, rs2296241, rs2762941, rs3787555, rs4809959, rs4809960, rs927650) and rs2298849. The polymorphisms FokI rs10735810/rs2228570, DBP rs4588, DBP rs7041 and rs2296241 are located in the exon region while rs703842 is situated in the $5^{\prime}$ flanking region (Supplementary Table 1 , see section on supplementary materials given at the end of this article, NCBI: http://www.ncbi.nlm.nih.gov).

SNP genotyping of Norwegian samples was performed using the Sequenom MassARRAY platform (Sequenom, San Diego) according to the manufacturer's instructions (http://www.sequenom.com) and explained in detail by Mitchell et al. (19). There was no deviation from HardyWeinberg equilibrium at any tested locus $(P>0.05)$.

\section{Statistical analysis}

Statistical analyses were performed using BiAS software, version 11 (epsilon-Verlag, Darmstadt, Germany).
Values for $25(\mathrm{OH}) \mathrm{D}_{3}(\mathrm{ng} / \mathrm{mL})$ and $1,25(\mathrm{OH})_{2} \mathrm{D}_{3}(\mathrm{pg} /$ $\mathrm{mL}$ ) (log base 10 transformed and not transformed) were checked for normal distribution using the KolmogorovSmirnov test.

As these values were not normally distributed, nonparametric statistical tests were applied.

We defined seasons as winter (November-March) and summer (April-October). The comparison of $25(\mathrm{OH})$ $\mathrm{D}_{3}$ (continuous variable) between summer and winter in each centre was done using Wilcoxon-Mann-Whitney- $U$ test.

The comparison of $25(\mathrm{OH}) \mathrm{D}_{3}$ and $1,25(\mathrm{OH})_{2} \mathrm{D}_{3}$ levels as continuous variables was performed separately for two centres using the Wilcoxon-Mann-Whitney- $U$-test. A subgroup analysis based on disease phenotype (isolated AAD/APS2) was also performed using the same test. The influence of the confounding factor season (summer, winter) but also sex on $25(\mathrm{OH}) \mathrm{D}_{3}$ levels was corrected using bi-factorial rank variance analysis.

The Chi square test was used to compare $25(\mathrm{OH})$ $\mathrm{D}_{3}$ deficiency (as a dichotomous variable) between $\mathrm{AAD}$ patients and healthy controls. Measurements were separated by the threshold of $25(\mathrm{OH}) \mathrm{D}_{3}<20 \mathrm{ng} / \mathrm{mL}$ (deficiency) and $>20 \mathrm{ng} / \mathrm{mL}$ (sufficiency) (20). The $P$ value for season was adjusted by Cochran-Mantel-Haenszel test.

The correlation analysis between the continuous variable $25(\mathrm{OH}) \mathrm{D}_{3}$ levels and genotypes was performed primarily using the Kruskal-Wallis test. If $\mathrm{a}_{\text {Pglobal }}<0.05$ was calculated, a subsequent post hoc test using an unpaired Wilcoxon-Mann-Whitney- $U$-test with Bonferroni correction was applied and adjusted for season using bi-factorial rank variance analysis

The Chi square test was used to examine the relationship between $25(\mathrm{OH}) \mathrm{D}_{3}$ deficiency (as a dichotomous variable) and the investigated SNPs and corrected for season using Cochran-Mantel-Haenszel test. The data are presented as medians, odds ratios (OR) and corresponding 95\% confidence intervals (95\% CI). $P$ values $\leq 0.05$ were regarded as being statistically significant.

\section{Results}

\section{5(OH) $\mathrm{D}_{3}$ levels in European cohorts}

The $25(\mathrm{OH}) \mathrm{D}_{3}$ status of most European AAD patients was vitamin D deficient with a plasma level of less than $20 \mathrm{ng} / \mathrm{mL}$. Only $7-14 \%$ of the patients had an optimal $25(\mathrm{OH}) \mathrm{D}_{3}$ level of $>30 \mathrm{ng} / \mathrm{mL}$. The proportion of vitamin D insufficient patients (20-30 $\mathrm{ng} / \mathrm{mL}$ ) ranged 
A

$25(\mathrm{OH}) \mathrm{D}_{3}<20 \mathrm{ng} / \mathrm{ml}$ and autoimmune Addison's disease

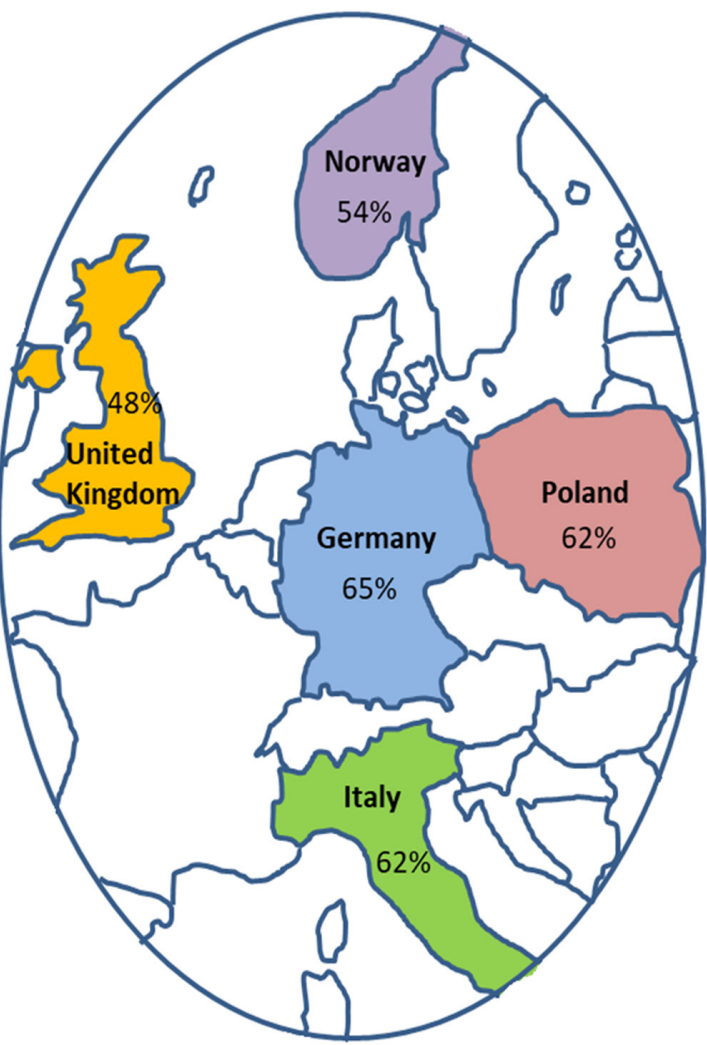

B

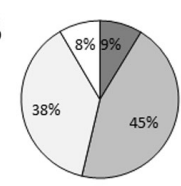

Norway

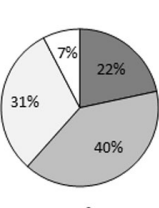

Italy

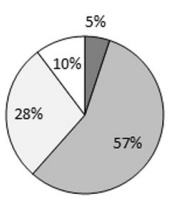

Poland

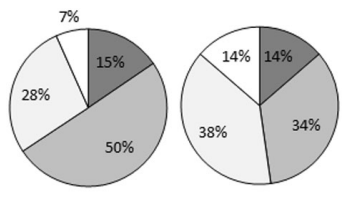

Germany UK

C

$25(\mathrm{OH}) \mathrm{D}_{3}(\mathrm{ng} / \mathrm{ml})$

607

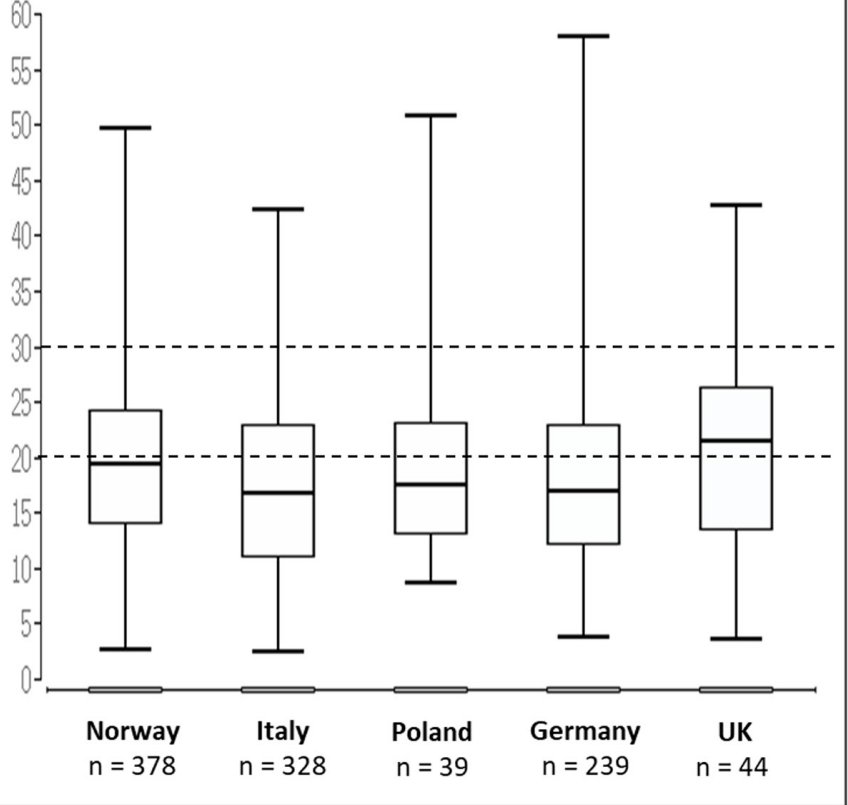

\section{Figure 1}

Distribution of autoimmune Addison's disease patients - from five European cohorts - according to 25(OH)D3 status. Categories (A) 25(OH)D3 deficiency (<20 ng/mL), (B) severely deficient $(\square<10 \mathrm{ng} / \mathrm{mL})$, deficient $(\square 10-20 \mathrm{ng} / \mathrm{mL})$,insufficient ( $\square 20-30 \mathrm{ng} / \mathrm{mL})$, optimal ( $\square>30 \mathrm{ng} / \mathrm{mL})$ and (C) 25(OH)D3 levels.

between 28-38\%, those deficient (10-20 ng/mL) 34-57\% and those severely deficient (<10 ng/mL) 5-22\% (Fig. 1A and $\mathrm{B}$ ).

The median $25(\mathrm{OH}) \mathrm{D}_{3}$ in the European $\mathrm{AAD}$ patients was <20 ng/mL: Italy $16.8 \mathrm{ng} / \mathrm{mL}$; Germany $17.0 \mathrm{ng} / \mathrm{mL}$; Norway $19.4 \mathrm{ng} / \mathrm{mL}$; Poland $17.5 \mathrm{ng} / \mathrm{mL}$ ), and only the United Kingdom patients'median was $21.3 \mathrm{ng} / \mathrm{mL}$ (Fig. 1C). $25(\mathrm{OH}) \mathrm{D}_{3}$ in $\mathrm{AAD}$ patients differed for the season of the blood collection: lower $25(\mathrm{OH}) \mathrm{D}_{3}$ was found in winter compared to the summer (Supplementary Fig. 1).

\section{Norwegian and German cohorts comparison of vitamin D levels between AAD and healthy controls}

A significant difference was found in median $25(\mathrm{OH})$ $\mathrm{D}_{3}$ between healthy controls and AAD patients for both
Norwegian (healthy controls $21.2 \mathrm{ng} / \mathrm{mL}$ vs AAD 19.4 $\mathrm{ng} / \mathrm{mL}$, Hodges-Lehmann estimate for the difference (HLS) was $2 \mathrm{ng} / \mathrm{mL}$ (95\% CI: 0.9, 3.)], adjusted for season $=P_{\text {adjusted }}=0.03$ ) and German cohorts (healthy controls $19.9 \mathrm{ng} / \mathrm{mL}$ vs AAD $17.0 \mathrm{ng} / \mathrm{mL}$, HLS $2.2 \mathrm{ng} / \mathrm{mL}$ $\left(95 \%\right.$ CI: 0.8, 3.8), $\left.P_{\text {adjusted }}=0.003\right)($ Fig. $2 A)$.

Furthermore, the median $1,25(\mathrm{OH})_{2} \mathrm{D}_{3}$ in $\mathrm{AAD}$ patients was lower (Norwegian AAD $45.7 \mathrm{pg} / \mathrm{mL}$ vs healthy controls $51.9 \mathrm{pg} / \mathrm{mL}$, HLS $6.2 \mathrm{pg} / \mathrm{mL}$ (95\% CI: 3.7,8.8), $P_{\text {adjusted }}=1 \times 10^{-5}$ and German AAD $41.7 \mathrm{pg} / \mathrm{mL}$ vs healthy controls $51.6 \mathrm{pg} / \mathrm{mL}$, HLS $10.1 \mathrm{pg} / \mathrm{mL}$ (95\% CI: 7.1,13.0), $P_{\text {adjusted }}<1 \times 10^{-7}$ ) (Fig. 2B).

Median $25(\mathrm{OH}) \mathrm{D}_{3}$ (effect estimate after Rosenthal $\mathrm{R}=0.13$; low effect $)$ and $1,25(\mathrm{OH})_{2} \mathrm{D}_{3}(\mathrm{R}=0.3$; medium effect) remained significantly different between AAD and healthy controls when stratifying for sex and disease phenotype (Supplementary Figs 2A, B and 3A, B). 


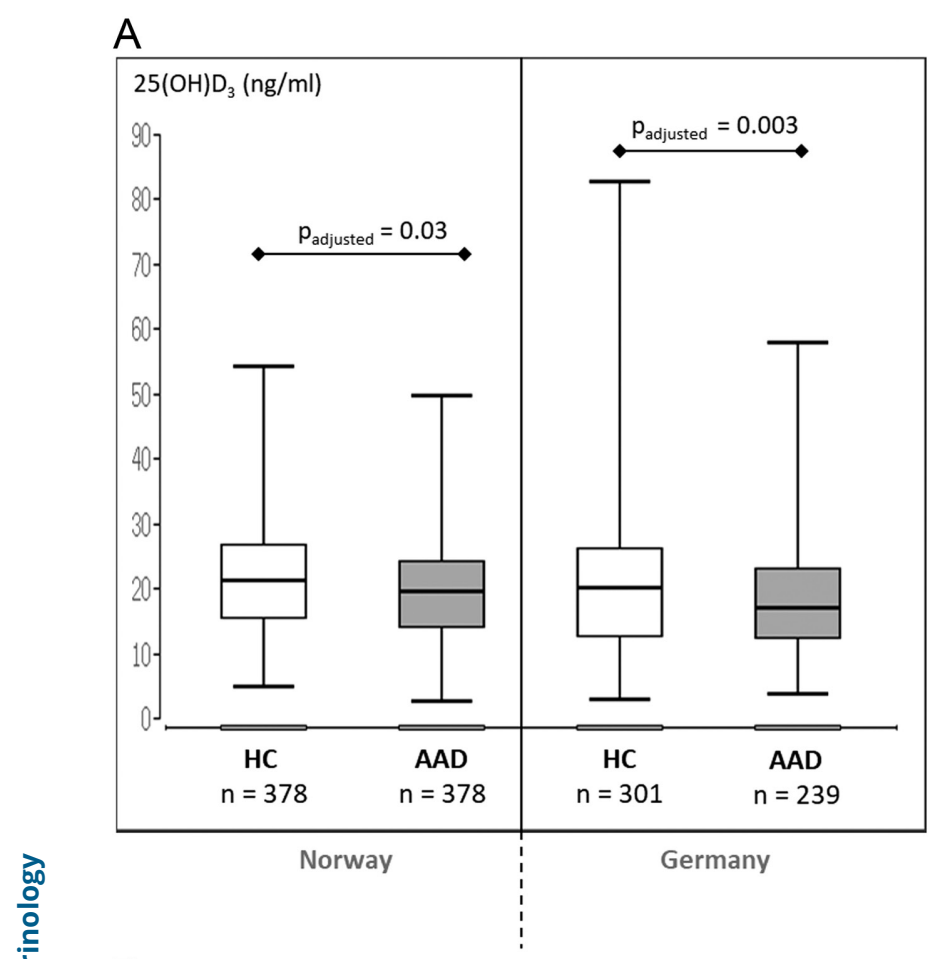

B

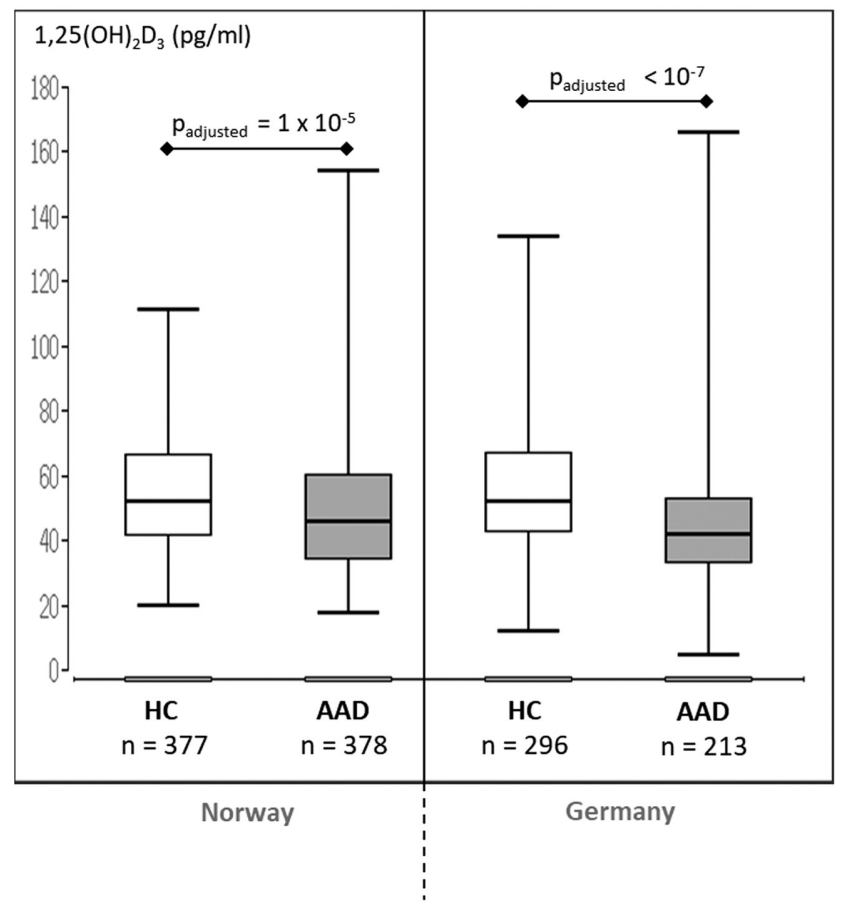

Figure 2

Comparison of $(\mathrm{A}) 25(\mathrm{OH}) \mathrm{D}_{3}(\mathrm{ng} / \mathrm{mL})$ and $(\mathrm{B}) 1,25(\mathrm{OH})_{2} \mathrm{D}_{3}(\mathrm{pg} /$ $\mathrm{mL}$ ) between patients with autoimmune Addison's disease (AAD) and healthy controls (HC) in Norway and Germany cohorts. $P$ values adjusted for season $=$ Padjusted .
Comparing $25(\mathrm{OH}) \mathrm{D}_{3}$ of controls and $\mathrm{AAD}$ patients over seasons, a significant difference was observed only in summers but not in winters: $25(\mathrm{OH}) \mathrm{D}_{3}$ were higher in healthy controls than in AAD in summers (Norway 21.9 vs $21.2 \mathrm{ng} / \mathrm{mL} P=0.08$ and Germany 21.4 vs $18.0 \mathrm{ng} /$ $\mathrm{mL} P=0.0002$ ) but winters (Norway $18.2 \mathrm{vs} 18.3 \mathrm{ng} /$ $\mathrm{mL}$ and Germany 16.2 vs $15.0 \mathrm{ng} / \mathrm{mL}$, both $P=0.72$ ) showed no difference (Supplementary Fig. 4). Overall, in the two-cohorts vitamin D deficiency is significantly more frequent in AAD patients than in healthy controls (Germany, OR: 1.92 (95\% CI: 1.34-2.76), $P_{\text {adjusted }}=0.0005$ and Norway, OR: 1.24 (95\% CI: 1.10-1.95), $\left.P_{\text {adjusted }}=0.18\right)$.

\section{Vitamin D metabolites and SNPs in vitamin D pathway genes}

Norwegian AAD patients carrying the genotypes GG of CYP2R1 rs1553006, had significantly lower 25(OH) $\mathrm{D}_{3}$ levels compared to healthy controls $\left(p_{\text {adjusted }}=0.004\right)$ (Table 2).

The allele G of CYP2R1 (rs1553006) was associated with vitamin $\mathrm{D}$ deficiency in the Norwegian patients (OR $\left.1.83, p_{\text {adjusted }}=0.0005\right)$. Allele $\mathrm{C}$ of CYP24A1 (rs3787555, OR 1.41), allele $\mathrm{T}$ of $V D R$ (rs2189480, OR 1.37) and allele $\mathrm{T}$ of $D B P$ (rs4588, OR 1.43) showed no association with vitamin $\mathrm{D}$ deficiency after adjustment ( $p_{\text {adjusted }}=0.1$, respectively), Table 3. No association was observed between $25(\mathrm{OH}) \mathrm{D}_{3}$ and other SNPs within VDR, CYP2R1, CYP27B1, CYP24A1 and $D B P$ in the Norwegian cohort (data not shown).

\section{Discussion}

We observe a high prevalence of vitamin D deficiency in AAD patients from five European cohorts. Only 7-14\% had a sufficient vitamin D status leaving the majority in various degrees of deficiency. AAD patients also suffering from APS were similarly affected by vitamin D deficiency. Vitamin D deficiency is a frequent finding both before and at onset of a range of autoimmune disorders (21). Low vitamin D levels may represent a long-standing cofactor in the pathophysiology of immune perturbations or just be an epiphenomenon. Vitamin D deficiency can be acquired, but has a strong genetic component. It is estimated that heritability accounts for $29 \%$ of the vitamin D status. In contrast UV-exposure is the major environmental contributor with nutritional intake having a minor impact $(22,23)$. Skin pigmentation is the primary threshold for UV light to generate the vitamin D precursor metabolite 7-dehydrocholesterol (7-DHC). Since AAD leads to both 
Table 2 25(OH)D $D_{3}(\mathrm{ng} / \mathrm{mL}$ ) levels and single nucleotide polymorphisms in vitamin $\mathrm{D}$ pathway genes in patients with autoimmune Addison's disease and healthy controls from Norway: correlation between the continuous $25(\mathrm{OH}) \mathrm{D}_{3}$ levels and genotypes.

\begin{tabular}{|c|c|c|c|c|c|}
\hline & \multicolumn{2}{|c|}{$n$} & \multicolumn{2}{|c|}{ 25(OH)D3 (ng/mL) } & \multirow[b]{2}{*}{${ }^{*} \boldsymbol{P}_{\text {adjusted }}$} \\
\hline & $\mathrm{HC}$ & AAD & $\mathrm{HC}$ & AAD & \\
\hline CYP2R1/rs1553006 & 290 & 320 & & & \\
\hline AA & & & 22.2 & 21.8 & \\
\hline GA & & & 20.9 & 19.4 & 0.7 \\
\hline GG & & & 21.3 & 16.9 & 0.004 \\
\hline CYP24A1/rs3787555 & 360 & 371 & & & \\
\hline AA & & & 21.4 & 17.8 & \\
\hline GA & & & 20.7 & 20.7 & \\
\hline GG & & & 21.7 & 18.3 & 0.02 \\
\hline CYP24A1/rs2181874 & 358 & 372 & & & \\
\hline $\mathrm{AA}$ & & & 17.2 & 16.0 & \\
\hline $\mathrm{GA}$ & & & 22.9 & 20.1 & 0.04 \\
\hline GG & & & 20.8 & 18.7 & 0.1 \\
\hline VDR/rs2189480 & 356 & 363 & & & \\
\hline TT & & & 21.8 & 17.0 & 0.12 \\
\hline GT & & & 20.6 & 18.9 & 0.06 \\
\hline GG & & & 21.4 & 20.4 & \\
\hline$D B P / r s 4588$ & 353 & 373 & & & \\
\hline TT & & & 21.3 & 14.4 & 0.02 \\
\hline GT & & & 20.9 & 19.5 & 0.28 \\
\hline GG & & & 21.7 & 19.5 & 0.13 \\
\hline
\end{tabular}

acute and chronic elevations of ACTH levels, (24) equimolar elevations of alpha-MSH enhance skin pigmentation. Many patients remain hyperpigmented despite adequate glucocorticoid and mineralocorticoid supplementation (25). Reduced UVB exposure is an established cause of vitamin D deficiency (26). This may contribute to vitamin D deficiency in AAD but needs to be studied further. Another reason is the regular glucocorticoid supplementation that may reduce the absorption of vitamin $\mathrm{D}$ in the gut. Taken together AAD patients will benefit from vitamin D supplementation throughout the year.

Our second finding is the genetic association of vitamin $\mathrm{D}$ deficiency with vitamin $\mathrm{D}$ pathway genes in patients. Hereby we can not distinguish whether the genetic determinants for vitamin $\mathrm{D}$ deficiency confer disease susceptibility via the low $25(\mathrm{OH}) \mathrm{D}_{3}$ levels or by a linked genetic mechanism, since most SNPs reside in introns and will affect regulation. Therefore only part of the explanation for vitamin $\mathrm{D}$ deficiency in $\mathrm{AAD}$ is genetic. Out of three key genes involved in vitamin D metabolism, two have been previously reported to be associated with AAD; namely variants within the DBP/GC and CYP27B1 loci $(6,27,28)$ alongside variants in the VDR gene $(29)$.

The gene encoding DBP/GC has the greatest effect on vitamin $\mathrm{D}$ status with genotypes in the top quartile displaying a two-fold risk for vitamin D insufficiency (30).
Another major gene is CYP2R1 that controls the hepatic hydroxylation to $25(\mathrm{OH})_{2} \mathrm{D}_{3}$. Allelic variation at this locus is consistently associated with vitamin $\mathrm{D}$ deficiency across several populations $(30,31)$. We find this gene to associate with vitamin $\mathrm{D}$ deficiency in Norwegian AAD patients. Another gene with major impact on vitamin D metabolism is NADSYN1/DHCR7 encoding the enzyme required for the generation of 7-DHC. Mutations in DHCR7 lead to the autosomal recessive Smith-Lemli-Opitz-syndrome, a rare polyendocrine disease manifesting with adrenal insufficiency, hypoparathyroidism, hypothyroidism and immune deficiency in the neonatal period accompanied by reduced cholesterol biosynthesis (32). Adequate supplementation of vitamin D in these cases may improve developmental outcomes in children.

Rare gene mutations with extreme phenotypes can illustrate a mechanism by which an endocrine metabolite such as vitamin D perturbs adrenal function. The more common genetic variants impacting vitamin D metabolism have more subtle effects which can be studied by Mendelian randomization where variants of the vitamin D system show effects on cytokine signalling (33). Furthermore, vitamin D regulates the gene expression of innate and acquired immunity genes, in particular the major histocompatibility complex class I and class II genes. For example, $1,25(\mathrm{OH})_{2} \mathrm{D}_{3}$ has the capacity to 
downregulate HLA-DR antigens on the surface of human monocytes and can dampen the immune response (34).

Active vitamin $\mathrm{D}$ acts on several genomic regions that are critical for the immune response, in particular the $H L A$ gene cluster on chromosome $6 \mathrm{p}$ (35). Elevated $25(\mathrm{OH})$ $\mathrm{D}_{3}$ levels after vitamin $\mathrm{D}$ treatment enhance chromatin accessibility allowing an epigenetic regulation of target genes. The epigenetic vitamin $\mathrm{D}$ response appears to be stronger in immune cells that are often capable of paracrine $1,25(\mathrm{OH})_{2} \mathrm{D}_{3}$ activation (36).

Vitamin D sufficiency in AAD should be achieved for three reasons: adequate intestinal calcium resorption, preventing secondary hyperparathyroidism and reducing fracture risk. Furthermore, a sufficient vitamin D status is required for a robust immune response. Patients with AAD depend on stable immunity because they are more vulnerable to infective agents that might trigger an adrenal crisis. Vitamin D supplementation may reduce the risk for acute respiratory infections particularly if patients were vitamin D deficient before supplementation (37). Patients with AAD are also at increased risk for additional autoimmune diseases, malignancies and cardiovascular disease (38). Vitamin D supplementation has a potential benefit in all three disease entities as systematic reviews suggest: by improving $\mathrm{T}$ regulatory function (39), reducing the risk of cancer death (40) or colorectal adenoma occurrence (41), and by lowering several risk factors for cardiovascular disease (42). Benefits of vitamin D supplementation were shown to vary depending on VDR genotypes (41). Another VDR SNP and one of CYP2R1 were associated with vitamin D deficiency in the Norwegian AAD cohort, illustrating that effects of vitamin D supplementation vary in different populations and dosing may need to be individualized to reach sufficiency.

Strengths of this study are the large size of the AAD patient cohorts from five European countries, and their vitamin D targeted clinical, biochemical and genetic analyses representing the biggest vitamin $\mathrm{D}$ investigation of this rare disease. A shortcoming is that healthy controls from only Norway and Germany were studied.

In summary, patients with $\mathrm{AAD}$ are at increased risk to develop vitamin D deficiency for clinical and genetic reasons. Vitamin D should be supplemented in order to prevent deficiency. Due to genetic variability in the vitamin $D$ response, the treatment should be to target by sufficiency testing. At present, vitamin D supplementation is not part of routine endocrine care in AAD but should be considered as such, in particular due to steroid comedication. Whether AAD patients will benefit from prophylactic effects on other comorbidities requires further study. 


\section{Limitations}

The Euradrenal consortium recruited the largest number of AAD patients possible. Healthy controls were only studied in Norway and Germany for this project part but not from Poland, Great Britain and Italy. Therefore AAD patients from these countries were studied for their vitamin D status without local controls.

$25(\mathrm{OH}) \mathrm{D}_{3}$ serum concentrations are largely confounded by nutrition, ethnicity and season (reflecting UVB exposure) which we reported for a German cohort (18). Here we corrected for the major confounding factor season (summer, winter). Since patients and controls were of Caucasian origin, ethnic confounders are negligible. The potential influence of diet was not determined.

\section{Supplementary materials}

This is linked to the online version of the paper at https://doi.org/10.1530/ EJE-20-0956.

\section{Declaration of interest}

Simon H S Pearce has received speaker fees from Sanofi, Quidel and Berlin Chemie, and has consulted for Apitope BV. The other authors have nothing to disclose.

\section{Funding}

This study was supported by grants from the European Union Framework 7 programme (grant number 201167, Euradrenal Consortium).

\section{Author contribution statement}

$\mathrm{MPM}$ and $\mathrm{K} \mathrm{B}$ wrote the manuscript and the other authors contributed to the final manuscript. G M, A S B W, B K, C B, A F, W O, D U, E S H, S H S P, $A L M$ and $K B$ recruited the study participants and collected clinical data. M P M, A L M and A S B W planned the study and were responsible for the genotyping and vitamin D metabolite analysis. M P M performed statistical analyses. All authors have approved the manuscript and agreed with its submission. We confirm that this manuscript has not been published elsewhere and is not under consideration by another journal.

\section{Acknowledgement}

The authors thank Prof. Anna Kasperlik-Zaluska (deceased on 7 March 2016) for providing patient data and samples.

\section{References}

1 Husebye ES, Anderson MS \& Kampe O. Autoimmune polyendocrine syndromes. New England Journal of Medicine 2018378 1132-1141. (https://doi.org/10.1056/NEJMra1713301)

2 Komisarenko YI \& Bobryk MI. Vitamin D deficiency and immune disorders in combined endocrine pathology. Frontiers in Endocrinology 20189 600. (https://doi.org/10.3389/fendo.2018.00600)

3 Sarkar S, Mondal R, Banerjee I \& Sabui T. Type II vitamin D-dependent rickets with diabetic ketoacidosis. Journal of Pediatric Endocrinology and Metabolism 201326 941-943. (https://doi. org/10.1515/jpem-2013-0137)
4 Nguyen M, d'Alesio A, Pascussi JM, Kumar R, Griffin MD, Dong X, Guillozo H, Rizk-Rabin M, Sinding C, Bougnères $\mathrm{P}$, et al. Vitamin D-resistant rickets and type 1 diabetes in a child with compound heterozygous mutations of the vitamin D receptor (L263R and R391S): dissociated responses of the CYP-24 and rel-B promoters to 1,25-dihydroxyvitamin D3. Journal of Bone and Mineral Research 2006 21 886-894. (https://doi.org/10.1359/jbmr.060307)

5 Torkildsen $\varnothing$, Knappskog PM, Nyland HI \& Myhr KM. Vitamin D-dependent rickets as a possible risk factor for multiple sclerosis. Archives of Neurology 200865 809-811. (https://doi.org/10.1001/ archneur.65.6.809)

6 Lopez ER, Zwermann O, Segni M, Meyer G, Reincke M, Seissler J, Herwig J, Usadel KH \& Badenhoop K. A promoter polymorphism of the CYP27B1 gene is associated with Addison's disease, Hashimoto's thyroiditis, Graves' disease and type 1 diabetes mellitus in Germans. European Journal of Endocrinology 2004151 193-197. (https://doi. org/10.1530/eje.0.1510193)

7 Alcina A, Fedetz M, Fernández O, Saiz A, Izquierdo G, Lucas M, Leyva L, García-León JA, Abad-Grau MM, Alloza I et al. Identification of a functional variant in the KIF5A-CYP27B1-METTL1-FAM119B locus associated with multiple sclerosis. Journal of Medical Genetics 201350 25-33. (https://doi.org/10.1136/jmedgenet-2012-101085)

8 Vanherwegen AS, Gysemans C \& Mathieu C. Regulation of immune function by vitamin $\mathrm{D}$ and its use in diseases of immunity. Endocrinology and Metabolism Clinics of North America 201746 1061-1094. (https://doi.org/10.1016/j.ecl.2017.07.010)

9 Panda DK, Miao D, Tremblay ML, Sirois J, Farookhi R, Hendy GN \& Goltzman D. Targeted ablation of the 25-hydroxyvitamin D 1alpha-hydroxylase enzyme: evidence for skeletal, reproductive, and immune dysfunction. PNAS 200198 7498-7503. (https://doi. org/10.1073/pnas.131029498)

10 Stoffels K, Overbergh L, Bouillon R \& Mathieu C. Immune regulation of 1alpha-hydroxylase in murine peritoneal macrophages: unravelling the IFNgamma pathway. Journal of Steroid Biochemistry and Molecular Biology 2007103 567-571. (https://doi.org/10.1016/j. jsbmb.2006.12.091)

11 Gysemans C, van Etten E, Overbergh L, Giulietti A, Eelen G, Waer M, Verstuyf A, Bouillon R \& Mathieu C. Unaltered diabetes presentation in NOD mice lacking the vitamin D receptor. Diabetes 200857 269-275. (https://doi.org/10.2337/db07-1095)

12 Bouillon R, Carmeliet G, Verlinden L, van Etten E, Verstuyf A, Luderer HF, Lieben L, Mathieu C \& Demay M. Vitamin D and human health: lessons from vitamin D receptor null mice. Endocrine Reviews 200829 726-776. (https://doi.org/10.1210/er.2008-0004)

13 Ishii M, Yamaguchi Y, Isumi K, Ogawa S \& Akishita M. Transgenic mice overexpressing vitamin D receptor (VDR) show antiinflammatory effects in lung tissues. Inflammation $2017 \mathbf{4 0}$ 2012-2019. (https://doi.org/10.1007/s10753-017-0641-2)

14 Singh PK, van den Berg PR, Long MD, Vreugdenhil A, Grieshober L, Ochs-Balcom HM, Wang J, Delcambre S, Heikkinen S, Carlberg $\mathrm{C}$ et al. Integration of VDR genome wide binding and GWAS genetic variation data reveals co-occurrence of VDR and NF-kappaB binding that is linked to immunephenotypes. BMC Genomics 201718 132. (https://doi.org/10.1186/s12864-017-3481-4)

15 Ramagopalan SV, Heger A, Berlanga AJ, Maugeri NJ, Lincoln MR, Burrell A, Handunnetthi L, Handel AE, Disanto G, Orton SM et al. A ChIP-seq defined genome wide map of vitamin D receptor binding: associations with disease and evolution. Genome Research 201020 1352-1360. (https://doi.org/10.1101/gr.107920.110)

16 Dekkers OM \& Groenwold RHH. Study design: what's in a name? European Journal of Endocrinology 2020183 E11-E13. (https://doi. org/10.1530/EJE-20-0873)

17 Reusch J, Ackermann H \& Badenhoop K. Cyclic changes of vitamin D and PTH are primarily regulated by solar radiation: 5-year analysis of a German (50 degrees N) population. Hormone and Metabolic Research 200941 402-407. (https://doi.org/10.1055/s-0028-1128131) 
18 Langer J, Penna-Martinez M, Bon D, Herrmann E, Wallasch M \& Badenhoop K. Insufficient vitamin D response to solar radiation in German patients with Type 2 diabetes or gestational diabetes. Hormone and Metabolic Research 201648 503-508. (https://doi. org/10.1055/s-0042-111685)

19 Mitchell AL, Macarthur KD, Gan EH, Baggott LE, Wolff AS, Skinningsrud B, Platt H, Short A, Lobell A, Kämpe O et al. Association of autoimmune Addison's disease with alleles of STAT4 and GATA3 in European cohorts. PLoS ONE 20149 e88991. (https://doi. org/10.1371/journal.pone.0088991)

20 Kroll MH, Bi C, Garber CC, Kaufman HW, Liu D, CastonBalderrama A, Zhang K, Clarke N, Xie M, Reitz RE et al. Temporal relationship between vitamin $\mathrm{D}$ status and parathyroid hormone in the United States. PLoS ONE 201510 e0118108. (https://doi. org/10.1371/journal.pone.0118108)

21 Ramagopalan SV, Goldacre R, Disanto G, Giovannoni G \& Goldacre MJ. Hospital admissions for vitamin D related conditions and subsequent immune mediated disease: record-linkage studies. BMC Medicine 201311 171. (https://doi.org/10.1186/1741-7015-11171)

22 Shea MK, Benjamin EJ, Dupuis J, Massaro JM, Jacques PF, D'Agostino Sr RB, Ordovas JM, O'Donnell CJ, Dawson-Hughes B, Vasan RS et al. Genetic and non genetic correlates of vitamins $\mathrm{K}$ and D. European Journal of Clinical Nutrition 200963 458-464. (https:// doi.org/10.1038/sj.ejcn.1602959)

23 Bouillon R. Genetic and environmental determinants of vitamin D status. Lancet 2010376 148-149. (https://doi.org/10.1016/S01406736(10)60635-6)

24 Sævik ÅB, Åkerman AK, Methlie P, Quinkler M, Jørgensen AP, Höybye C, Debowska AJ, Nedrebø BG, Dahle AL, Carlsen S et al. Residual corticosteroid production in autoimmune Addison disease. Journal of Clinical Endocrinology and Metabolism 2020105 2430-2441. (https://doi.org/10.1210/clinem/dgaa256)

25 Hall TC, Mccracken BH \& Thorn GW. Skin pigmentation in relation to adrenal cortical function. Journal of Clinical Endocrinology and Metabolism 195313 243-257. (https://doi.org/10.1210/jcem-13-3-243)

26 Webb AR, Kazantzidis A, Kift RC, Farrar MD, Wilkinson J \& Rhodes LE. Colour counts: sunlight and skin type as drivers of vitamin D deficiency at UK latitudes. Nutrients 201810 457. (https:// doi.org/10.3390/nu10040457)

27 Jennings CE, Owen CJ, Wilson V \& Pearce SH. A haplotype of the CYP27B1 promoter is associated with autoimmune Addison's disease but not with Graves' disease in a UK population. Journal of Molecular Endocrinology 200534 859-863. (https://doi.org/10.1677/jme.1.01760)

28 Fichna M, Zurawek M, Januszkiewicz-Lewandowska D, Gryczyñska M, Fichna P, Sowiñski J \& Nowak J. Association of the CYP27B1 C(-1260)A polymorphism with autoimmune Addison's disease. Experimental and Clinical Endocrinology and Diabetes 2010118 544-549. (https://doi.org/10.1055/s-0029-1241206)

29 Pani MA, Seissler J, Usadel KH \& Badenhoop K. Vitamin D receptor genotype is associated with Addison's disease. European Journal of Endocrinology 2002147 635-640. (https://doi.org/10.1530/ eje.0.1470635)

30 Wang TJ, Zhang F, Richards JB, Kestenbaum B, van Meurs JB, Berry D, Kiel DP, Streeten EA, Ohlsson C, Koller DL et al. Common genetic determinants of vitamin D insufficiency: a genome-wide association study. Lancet 2010376 180-188. (https://doi.org/10.1016/S01406736(10)60588-0)

31 Duan L, Xue Z, Ji H, Zhang D \& Wang Y. Effects of CYP2R1 gene variants on vitamin $D$ levels and status: a systematic review and meta-analysis. Gene 2018678 361-369. (https://doi.org/10.1016/j. gene.2018.08.056)

32 Donoghue SE, Pitt JJ, Boneh A \& White SM. Smith-Lemli-Opitz syndrome: clinical and biochemical correlates. Journal of Pediatric Endocrinology and Metabolism 201831 451-459. (https://doi. org/10.1515/jpem-2017-0501)

33 Chun RF, Liu PT, Modlin RL, Adams JS \& Hewison M. Impact of vitamin D on immune function: lessons learned from genome-wide analysis. Frontiers in Physiology 20145 151. (https://doi.org/10.3389/ fphys.2014.00151)

34 Tokuda N, Mizuki N, Kasahara M \& Levy RB. 1,25-Dihydroxyvitamin D3 down-regulation of HLA-DR on human peripheral blood monocytes. Immunology 199275 349-354.

35 Carlberg C, Seuter S, Nurmi T, Tuomainen TP, Virtanen JK \& Neme A In vivo response of the human epigenome to vitamin D: a proof-ofprinciple study. Journal of Steroid Biochemistry and Molecular Biology 2018180 142-148. (https://doi.org/10.1016/j.jsbmb.2018.01.002)

36 Carlberg C. Vitamin D signaling in the context of innate immunity: focus on human monocytes. Frontiers in Immunology 2019102211. (https://doi.org/10.3389/fimmu.2019.02211)

37 Martineau AR, Jolliffe DA, Greenberg L, Aloia JF, Bergman P, DubnovRaz G, Esposito S, Ganmaa D, Ginde AA, Goodall EC et al. Vitamin D supplementation to prevent acute respiratory infections: individual participant data meta-analysis. Health Technology Assessment 201923 1-44. (https://doi.org/10.3310/hta23020)

38 Bensing S, Brandt L, Tabaroj F, Sjöberg O, Nilsson B, Ekbom A, Blomqvist P \& Kämpe O. Increased death risk and altered cancer incidence pattern in patients with isolated or combined autoimmune primary adrenocortical insufficiency. Clinical Endocrinology 200869 697-704. (https://doi.org/10.1111/j.1365-2265.2008.03340.x)

39 Fisher SA, Rahimzadeh M, Brierley C, Gration B, Doree C, Kimber CE, Plaza Cajide A, Lamikanra AA \& Roberts DJ. The role of vitamin D in increasing circulating $\mathrm{T}$ regulatory cell numbers and modulating $\mathrm{T}$ regulatory cell phenotypes in patients with inflammatory disease or in healthy volunteers: a systematic review. PLOS ONE 201914 e0222313. (https://doi.org/10.1371/journal.pone.0222313)

40 Zhang Y, Fang F, Tang J, Jia L, Feng Y, Xu P \& Faramand A. Association between vitamin D supplementation and mortality: systematic review and meta analysis. BMJ 2019366 14673. (https:// doi.org/10.1136/bmj.14673)

41 Barry EL, Peacock JL, Rees JR, Bostick RM, Robertson DJ, Bresalier RS \& Baron JA. Vitamin D receptor genotype, vitamin D3 supplementation, and risk of colorectal adenomas: a randomized clinical trial. JAMA Oncology 20173 628-635. (https://doi. org/10.1001/jamaoncol.2016.5917)

42 Mirhosseini N, Rainsbury J \& Kimball SM. Vitamin D supplementation, serum $25(\mathrm{OH}) \mathrm{D}$ concentrations and cardiovascular disease risk factors: a systematic. Review and meta-analysis. Frontiers in Cardiovascular Medicine 20185 87. (https://doi.org/10.3389/ fcrm.2018.00087)

Received 21 August 2020

Revised version received 23 December 2020

Accepted 12 January 2021 